Rev. Int. Contam. Ambie. 36 (3) 567-575, 2020

https://doi.org/10.20937/RICA.53027

\title{
HEAVY METALS BIOABSORPTION AND SOIL STABILIZATION BY Sarcocornia neei FROM EXPERIMENTAL SOILS CONTAINING MINE TAILINGS
}

Bioabsorción de metales pesados y estabilización de suelo por Sarcocornia neei desde suelos experimentales conteniendo relaves mineros

Bernardo SEPÚLVEDA ${ }^{1 *}$, Mario TAPIA ${ }^{2}$, Patricia TAPIA $^{2}$, Francisca MILLA $^{2}$ and Osvaldo PAVEZ ${ }^{1}$

${ }^{1}$ Centro Regional de Investigación y Desarrollo Sustentable de Atacama - CRIDESAT, Universidad de Atacama, Av. Copayapu 485, Copiapó, Chile

${ }^{2}$ Departamento de Ingeniería en Metalurgia, Universidad de Atacama Av. Copayapu 485, Copiapó, Chile

*Autor de correspondencia: bernardo.sepulveda@uda.cl

(Received November 2017, accepted March 2020)

Key words: Atacama-Copiapó, metalophytes, phytorremediation, Mn-bioabsorption

\begin{abstract}
In the Atacama region of northern Chile, there are a large number of abandoned mines and dams with tailings and little flora development. Sarcocornia neei, a halophytic plant growing in Chilean coastal areas, is highly tolerant to contaminated soils associated with mine tailings. The potential for bioabsorption of heavy metals and arsenic and the substrate stabilization by this species was evaluated in soil experimentally contaminated with mine tailings from the Copiapó Valley. Sarcocornia neei grew well, although more slowly, in experimental soils containing mainly $\mathrm{Fe}, \mathrm{Cu}$ and $\mathrm{Mn}$. In an advanced vegetative development stage, $S$. neei roots were able to stabilize the contaminated experimental soils, agglomerating them in more than $80 \%$ and extracting chemical elements from them. These characteristics are potentially useful for phytoremediation and reduction of contamination by fine-size particles from mine tailings and contaminated soils.
\end{abstract}

Palabras clave: Atacama-Copiapó, metalofitas, fitorremediación, bioabsorción de Mn

\section{RESUMEN}

En la región de Atacama, en el norte de Chile, hay una gran cantidad de minas y depósitos de relaves abandonados con poco desarrollo de flora. Sarcocornia neei, una planta halófita que crece en zonas costeras de Chile, es altamente tolerante a los suelos contaminados asociados con relaves mineros. El potencial de esta especie para la bioabsorción de metales pesados y arsénico y la estabilización del sustrato se evaluó en suelo contaminado experimentalmente con relaves mineros del Valle de Copiapó. Sarcocornia neei creció bien, aunque más lentamente, en suelo conteniendo principalmente $\mathrm{Fe}, \mathrm{Cu}$ y $\mathrm{Mn}$. En etapa de desarrollo vegetativo avanzado, las raíces de $S$. neei fueron capaces de estabilizar los suelos experimentales contaminados, aglomerándolos en más de $80 \%$ y extrayendo elementos químicos de ellos. Estas características son potencialmente útiles para la fitorremediación y reducción de la contaminación por partículas de tamaño fino, provenientes de relaves y suelos contaminados. 


\section{INTRODUCTION}

In the Atacama Region of northern Chile, metal concentration processes generate large amounts of mine tailings containing environmentally deleterious heavy metals and arsenic (Ginocchio 1996, Ginocchio and Baker 2004, Montenegro et al. 2009). Mine tailings have a sandy loam texture and low organic matter content (Cornejo et al. 2008, Montenegro et al. 2009), unfavorable for vegetation growth (Lambers et al. 1998). However, there is a slow process called re-vegetation, which shows the existence of biological mechanisms in plants with resistance to metal phytotoxicity in the colonization of these areas (Lambert et al. 1998, Reeves 2003, Guinocchio and Baker 2004, Iannacone and Alvariño 2005, Reeves and Baker 2000). Plants growing in mine tailings are metallophytes, because of their ability to accumulate high concentrations of metals in their tissues relative to other plant types (Lasat 2002, Reeves 2003).

The extent and variety of metallic mineral deposits in Chile, make the metallophyte plants an important genetic source (Lasat 2002, Reeves 2003). About 400 metallophyte plant species have been described worldwide (Reeves 2003, Cunningham and Ow 1996) from New Caledonia, Philippines, Brazil, Chile, Cuba and Brazil, among other countries; in Chile, 54 native plant species have been evaluated, $63 \%$ of them were $\mathrm{Cu}$ tolerant (Ginocchio and Baker 2004).

Sarcocornia neei can extract heavy metals (Figueroa et al. 1987, Costa 2011); in previous works, Sepúlveda et al. $(2012,2017)$ reported the capacity of this species to grow in pure mine tailings, bioabsorbing high $\mathrm{Fe}$ and $\mathrm{Mn}$ concentration, without suffering major phytoxicity. On the other hand, $S$. neei develops a root system that allows soil retention; then, it is possible that this species could potentially be used for phytoremediation and rehabilitation of soils contaminated with mine tailings.

The goal of this work was to determine the capacity of Sarcocornia neei to grow in soil experimentally contaminated with copper mine tailings, determining its ability to bioabsorb $\mathrm{Cu}, \mathrm{Fe}, \mathrm{Mn}, \mathrm{Mo}, \mathrm{As}, \mathrm{Hg}$, and $\mathrm{Cd}$ and to quantify its ability to stabilize the experimental soil.

\section{MATERIALS AND METHODS}

\section{Samples of Sarcocornia neei}

The plant species $S$. neei inhabits the seacoast of Atacama, and at the mouths of the rivers. It is a halophyte species, so it develops in populations near the coast; the sand where $S$. neei grows was named "native sand", to differentiate it from other materials. The town of Bahía Salada (27018'12 "S - 70 55 '53" W, $76 \mathrm{~km}$ west of Copiapó) was the only source for obtaining native sand and plant material such as cuttings and seeds.

\section{Experimental soils}

To obtain the experimental soils, two abandoned mine tailings were sampled; one of them is located on the shore of the Copiapó River (27'21'20 "S and $70^{\circ} 21^{\prime} 14^{\prime \prime} \mathrm{W}, 360$ meters above sea level); this is a deposit that contains mine tailings from copper, gold and silver mines and close to an old metal smelter. The second is a deposit that contains mine tailings from a copper mine located at $203 \mathrm{~km} \mathrm{NE}$ from Copiapó; the material was obtained from a depth from 0 to $50 \mathrm{~cm}$. Each sample was divided using the cone and crushing technique, an 18 mesh screen was used to disperse the material. Each one of the final mine tailings samples was used to make experimental soil mixtures for $S$. neei cultivation. The experimental soils were prepared from native sand and the two tailings. The prepared substrates were (1) $100 \%$ native beach sand, (2) $100 \%$ mine tailings 1, (3) $100 \%$ mine tailings 2, (4) mixture of sand and mine tailings 1 (1: 1) and (5) mixture of sand and mine tailings 2 (1: 1).

\section{Seed germination and emergence of $S$. neei seed- lings assay}

The seeds were collected from $S$. neei plants from Bahía Salada at the end of the summer (February). The seeds were ordered superficially (100 seeds) in five petri dishes (repetitions), containing a $5 \mathrm{~mm}$ thick layer of each experimental soil. The seeds were covered with a thin layer of the same experimental soil. The experimental plantations were watered at $50 \%$ of their field capacity (determined for each case) every two days. The proportion (\%) of germinated seeds, and emergency seedlings was recorded.

From this trial, seedlings transplanted to pots containing the different mentioned experimental soils were obtained; the growth rate of $S$. neei was determined in each case, measuring the plants height daily.

\section{Bioabsorption of metals and As by Sarcocornia neei plants}

To prepare $S$. neei plants for the bioabsorption assay, cuttings of at least $20 \mathrm{~cm}$ of $S$. neei branches were obtained from Bahía Salada beach. Plant cuttings were induced to root formation by immersion in a commercial solution of IBA ( $20 \%$ indole 
butiric acid), for a period of at least 24 hours. Rooted cuttings were transplanted into vials containing the above mentioned experimental soils; at least, 250 plants were distributed in five treatments (experimental soils and controls), five repetitions that included the double number of individual plants, to ensure the repetitions. The plants were maintained in each soil experimental and controls, under conditions similar to those mentioned above for the germination assay. The plants grew in an external environment with natural thermal variation $\left(14\right.$ to $\left.25^{\circ} \mathrm{C}\right)$. From the total of plants, at 30 days, a random sample of five individuals (complete plant) of $S$. neei by treatment (experimental soils) were dried under shade conditions, until the constant weight was reached.

To determinate the concentration of $\mathrm{Fe}, \mathrm{Cu}, \mathrm{Mn}$, $\mathrm{Mo}, \mathrm{Hg}, \mathrm{Cd}$ and $\mathrm{As}$ in $\mathrm{S}$. neei, $5 \mathrm{~g}$ of dry and pulverized plant material of each treatment was processed, using the same protocol for the inert materials (native sand, mine tailings and experimental soils); the procedure will be described in the following section.

\section{Concentration of metals and As from sand, mine tailings and experimental soils}

The diverse materials were characterized for $\mathrm{Fe}$, $\mathrm{Cu}, \mathrm{Mn}, \mathrm{Mo}, \mathrm{Hg}, \mathrm{Cd}$ and $\mathrm{As}$ in the Scientific and Technological Research Institute of the University of Atacama (Instituto de Investigación Científica y Tecnológica, Universidad de Atacama; IDICTEC-UDA) using standard methods referenced for the analysis of sludge, tailings, soils and plants (Sadzawka et al. 2007, Sandoval et al. 2011).

To analyze the samples of mine tailings (geochemical background or control) and experimental soils, $5 \mathrm{~g}$ of each material was dried in an oven at $105^{\circ} \mathrm{C}$ during 6 hours; the analyses were made in triplicate, and the relative humidity was used as a correction factor to calculate concentrations.

To determine the concentration of $\mathrm{Fe}, \mathrm{Cu}, \mathrm{Mn}$, $\mathrm{Mo}, \mathrm{Cd}$ and As, 1 to $2 \mathrm{~g}$ of each material were used; $25 \mathrm{~mL}$ of $\mathrm{HNO}_{3}$ was added to each sample, the mix was digested on a heating plate at $80{ }^{\circ} \mathrm{C}$. Once the volume had been reduced at approximately $5 \mathrm{~mL}$, the samples were cooled and $5 \mathrm{~mL}$ of perchloric acid was added; this is a common step to determine any element, including $\mathrm{Hg}$. The mixtures were heated until reaching a high viscosity (syrupy) liquid state, at $200^{\circ} \mathrm{C} ; 2 \mathrm{~mL}$ of concentrated $\mathrm{HCl}$ was then added, and the volume was filled up to $100 \mathrm{~mL}$ with distilled water. The $\mathrm{Cu}$ and $\mathrm{Pb}$ concentrations were determined by flame atomic absorption spectrophotometry using a GBC Avanta atomic absorption spectrophotometer, and a HG-3000 hydride generator was coupled to the spectrophotometer to determinate arsenic concentration.

To determine $\mathrm{Hg}$ concentration, the same initial process for non-mercury elements earlier described was used; after the acidic digestion and volume reduction, $10 \mathrm{~mL}$ of royal water was added, and the mixture was heated on a heating plate to $200{ }^{\circ} \mathrm{C}$ until the brown vapor dissipated. The mixture was cooled and $15 \mathrm{~mL}$ of $\mathrm{KMnO}_{4}$ was added, then the mixture was stirred and allowed the reaction overnight. If the reaction mixture turned pink, $5 \mathrm{~mL}$ of $\mathrm{KMnO}_{4}$ was added, and it was analyzed after one hour. Finally, 2 $\mathrm{mL}$ of $\mathrm{NaCl}$ solution and hydroxylamine was added to neutralize the excess of oxidant; the solution was then flush to $50 \mathrm{~mL}$ with distilled water. The cold vapor technique to determine the presence of $\mathrm{Hg}$ was used, using a $\mathrm{Hg}$ analyzer $\mathrm{Hg}-254 \mathrm{~N}$. Concentrations of $\mathrm{Hg}$ greater than $25 \mathrm{~g} /$ per ton were analyzed by flame atomic absorption. The result was expressed as $\mathrm{mg} / \mathrm{kg}$ of solid on dry sample basis.

\section{Experimental soils compacting trial by Sarcocor- nia neei}

To characterize the granulometry of the materials (sand, mine tailings and experimental soils) a Malvern particle size analyzer (Mastersize Hydro 2000) was used. Samples of $10 \mathrm{~g}$ of each material were suspended in $20 \mathrm{~mL}$ of distilled water and were scattered by ultrasound during one minute. Calibration curves of the experimental soils were obtained; sand, silt, and clay proportion (\%) of each material was determined by interpolation. Each one of the pure and mixed inert materials to $S$. neei growing was assimilated to a soil type, according to the soil triangle (Sandoval 2011).

To prepare the assay of experimental soils and field capacity, experimental soils were prepared from mine tailing/native sand ratios of 100/0, 80/20,60/40, $40 / 60$ and $0 / 100 \%$. Field capacity was determined according to a common practical protocol: Each experimental soil (mixture) was placed in a PVC cylinder, with a fine synthetic mesh covering the lower end, the initial dry weight of the total system was recorded. Water was added to each cylinder, until it dripped by gravity. When the cylinders stopped dripping, the water content was determined by weight difference. This provided a measure of field capacity, and was used as irrigation reference (Cairo and Reyes 2017).

For the agglomeration of experimental soils by plant trial, experimental soils were placed in transparent $(250 \mathrm{~mL})$ polyethylene vials, with 30 replicates for each experimental soil mixture. Each pot was 
saturated with water at field capacity, and rooted plants were transplanted. The vials were covered with black polyethylene $(15 \times 20 \mathrm{~cm})$ bags. The transparency of the pots allowed observing the development of the plant roots in each time of sampling. Plants were watered to at least $50 \%$ of field capacity every three days. Assays were evaluated at 80,110 and 140 days after transplanting. At each sampling period, 10 vials were labeled for each experimental soil (by triplicate) and irrigation was stopped one week before the analysis. In each sampling time the canopy height was measured; the vials were removed, and the weight of fresh plant plus experimental soil were determined. Then, the plants were gently shaken until the experimental soil, which was not retained, stopped pulling away from the roots; the wet plant weight plus the retained experimental soil by roots were recorded.

Each plant was separated from the retained up experimental soil; the retained experimental soil by plant roots was calculated by weight difference; the canopy height $(\mathrm{cm})$ was determined and the canopy and root were separated. The weight $(\mathrm{g})$ of each fresh plant fraction and wet agglomerated and free experimental soil were recorded. All of the previous fractions of plant and experimental soils were dried at $105{ }^{\circ} \mathrm{C}$ until constant weight, and the dry weight of each one was recorded.

\section{Data analysis}

The data were analyzed using Student's t-test for paired samples, that matches samples with the same number of data and different variance. The significance of the differences between treatment results is represented by the symbol "p", a statistical error $\alpha$ between $5(\mathrm{p}=0.05)$ and $10 \%(\mathrm{p}=0.1)$, meaning
$90 \%$ and $95 \%$ of confidence; if the value of $p$ is lower than $\alpha$, the result (difference) is statistically significant.

\section{RESULTS}

\section{Germination of seeds of Sarcocornia neei in ex- perimental soils}

The germination of seeds $(96.7 \pm 1.5 \%)$ was statistically similar in the different experimental soils. This result confirms that $S$. neei can germinate and grow well in mine tailings and mixes. The plants emerged were the same germinated $(96.7 \%)$, with $100 \%$ of survival in the trial.

\section{Concentration of metals and As in Sarcocornia neei and experimental soils}

The concentration of elements $(\mathrm{mg} / \mathrm{kg}$ of dry weight) in the different soils is shown in Table I. In the mine tailings the concentration of Fe $(249000 \mathrm{mg} /$ $\mathrm{kg} \mathrm{dw}$ ), was 75 times higher than in $S$. neei related to beach sand (field control, $3333 \mathrm{mg} / \mathrm{kg} \mathrm{dw}$ ), and 55 times higher than in $S$. neei before the trial (4557.9 $\mathrm{mg} / \mathrm{kg} \mathrm{dw}$ ). In $S$. neei post-assay, Fe concentration was 1.4 times higher than in the Bahía Salada wild plants. The concentration of $\mathrm{Cu}$ in mine tailings was $946 \mathrm{mg} / \mathrm{kg}$ dw, 95 times higher than in wild $S$. neei from Bahía Salada (10 mg/kg dw), and five times higher than $S$. neei before the trial $(182.6 \mathrm{mg} / \mathrm{kg} \mathrm{dw})$. In $S$. neei post-assay, $\mathrm{Cu}$ concentration was 18 times higher than in control plants. The concentration of Mn in mine tailings ( $185 \mathrm{mg} / \mathrm{kg}$ of dw) was statistically similar to the concentration in $S$. neei before the trial $(135.6 \mathrm{mg} / \mathrm{kg}$ of $\mathrm{dw})$. No other elements were important. Sarcocornia neei accumulates mainly

TABLE I. CONCENTRATIONS OF CHEMICAL ELEMENTS

\begin{tabular}{lcccc}
\hline Element & \multicolumn{4}{c}{ Sample } \\
\cline { 2 - 5 } & $\begin{array}{c}\text { Mine tailings } \\
(\mathrm{mg} / \mathrm{kg})\end{array}$ & $\begin{array}{c}\text { Sarcocornia control } \\
(\text { from beach }) \\
(\mathrm{mg} / \mathrm{kg} \mathrm{dw})(\mathrm{A})\end{array}$ & $\begin{array}{c}\text { Sarcocornia } \\
\text { post-assay } \\
(\mathrm{mg} / \mathrm{kg} \mathrm{dw})(\mathrm{B})\end{array}$ & A-B (\%) \\
\hline $\mathrm{Cu}$ & $946 \mathrm{a}$ & $182,6 \mathrm{c}$ & 94.5 \\
$\mathrm{Fe}$ & $249000 \mathrm{~d}$ & $3333 \mathrm{e}$ & $4557,9 \mathrm{f}$ & 26.9 \\
$\mathrm{Mn}$ & $185 \mathrm{c}$ & 0 & $135,6 \mathrm{c}$ & 100 \\
$\mathrm{Mo}$ & $15.6 \mathrm{~b}$ & $\mathrm{ND}$ & $<5$ & $\mathrm{ND}$ \\
$\mathrm{As}$ & 12.5 & 0.43 & 2,84 & $\mathrm{ND}$ \\
$\mathrm{Hg}$ & 0.30 & 0.14 & 0,49 & $\mathrm{ND}$ \\
$\mathrm{Cd}$ & $<0.5$ & $\mathrm{ND}$ & $<0,25$ & $\mathrm{ND}$ \\
\hline
\end{tabular}

$\mathrm{mg} / \mathrm{kg} \mathrm{dw}=\mathrm{mg} / \mathrm{kg}$ per dry weight. ND $=$ Not detected, $<\mathrm{x}=$ below detectable limits of equipment. The same letter ( $a, b, c, d$, e or $f$ ) added at right of more than one value indicates statistical similarity between them. 
(99.8 \%) $\mathrm{Fe}, \mathrm{Cu}, \mathrm{Mn}$, and $\mathrm{Hg}$, although the presence of this last element was low.

The difference of concentration in $S$. neei between treatments (native sand as control), showed that the plants absorbed $94.5 \% \mathrm{Cu}, 27 \% \mathrm{Fe}$ and $100 \%$ Mn from the environmental content in natural conditions. Although the element present at highest concentrations was $\mathrm{Fe}$, the main gain of $S$. neei was in manganese, since the native concentration (sand beach) in $S$. neei was close to zero, showing high affinity to this element when it was available in the experimental soil.

\section{Retention of experimental soil trial by Sarcocor- nia neei}

Changes in the growth rate of canopy of $S$. neei in both experimental soils with mine tailings, between sampling times were evaluated (Fig. 1). The growth response was essentially homogeneous, there was no significant difference $(p=0.15)$ neither between different experimental soils nor sampling times. This result allowed us to calculate an average overall growth rate of $0.102+0.01 \mathrm{~cm} /$ day.

On the other hand, there was no significant difference $(p=0.23)$ in weight gain response of plants between the different experimental soils, in all the sampling period. However, from T80 $(\mathrm{T}=$ time $)$ to T110 days, the weight change rate (Fig. 2) was 40.5 $\%$ higher in the experimental soil containing mine

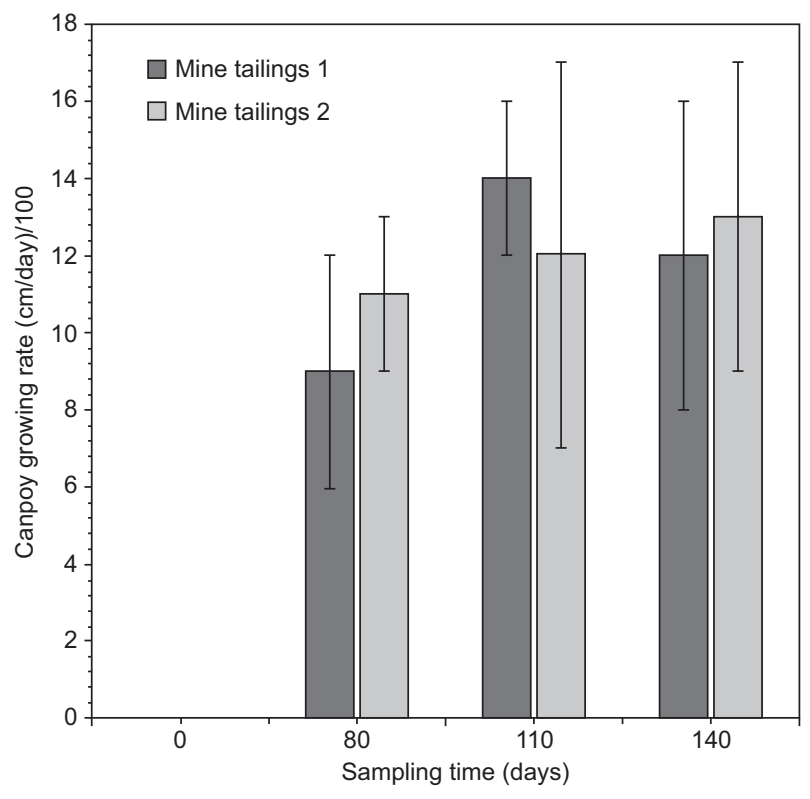

Fig. 1. Canopy growing rate (cm/day) from Sarcocornia neei in experimental soils tailings 1 , and $27.7 \%$ higher in the experimental soil containing mine tailings $2(p=0.04)$. This result had significant implications for the experimental soil retention trial.

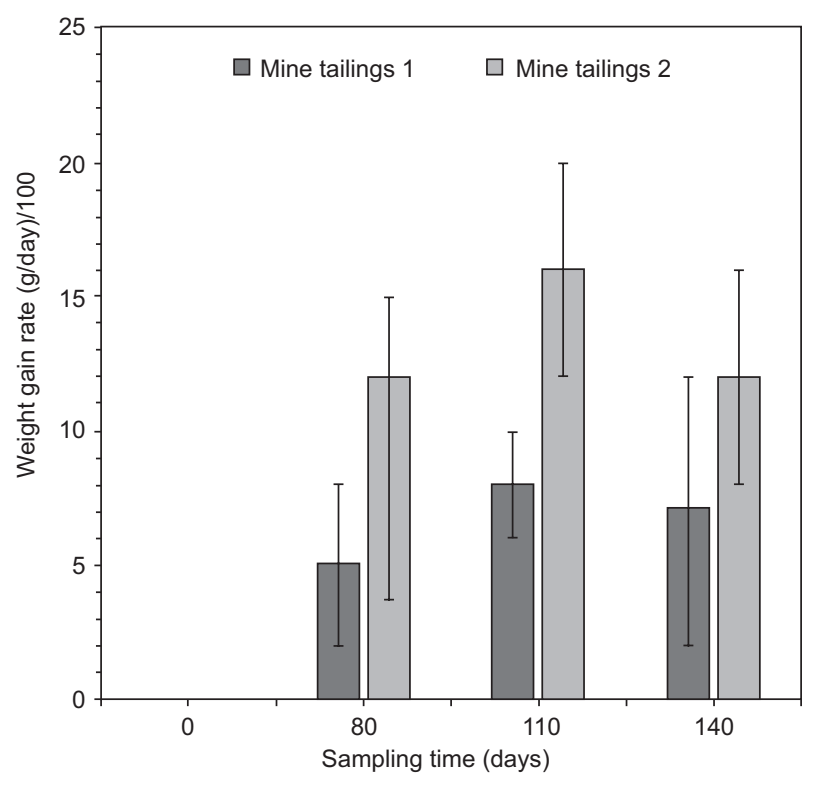

Fig. 2. Weight gain rate (g/day) from Sarcocornia neei growing in experimental soils

In the evaluation of experimental soil retention (Fig. 3), the proportion of agglomerated experimental soil was statistically similar $(\mathrm{p}>0.05)$ for all the experimental soils in each sampling time; allowing to obtain an average for each sampling time and mine tailings. The proportion (\%) of retained experimental soil was significantly different $(\mathrm{p}<0.005)$ for each sampling time and related to T0 sample, indicating that experimental soil retention is a function of plant root development. Confronting the retention of experimental soil, just the retention of experimental soil at T140 was higher than T80 $(\mathrm{p}=0.01)$ using mine tailings 1 .

Using mine tailings 2 , the retention of experimental soil was significantly different $(p=0.03)$ in the three sampling times, it increased over time T80 (19.2\%) $<$ T110 $(46 \%)<$ T140 (69.4\%). The matching of retention of experimental soil at each sampling time between mine tailings 1 and 2 showed that retention was significantly higher in experimental soils containing the mine tailings 1 at T80 days $(60.2 \%, \mathrm{p}=$ $0.02), 110$ days $(66.7 \%, \mathrm{p}=0.03)$, and at 140 days $(82.3 \%, \mathrm{p}=0.01)$. 


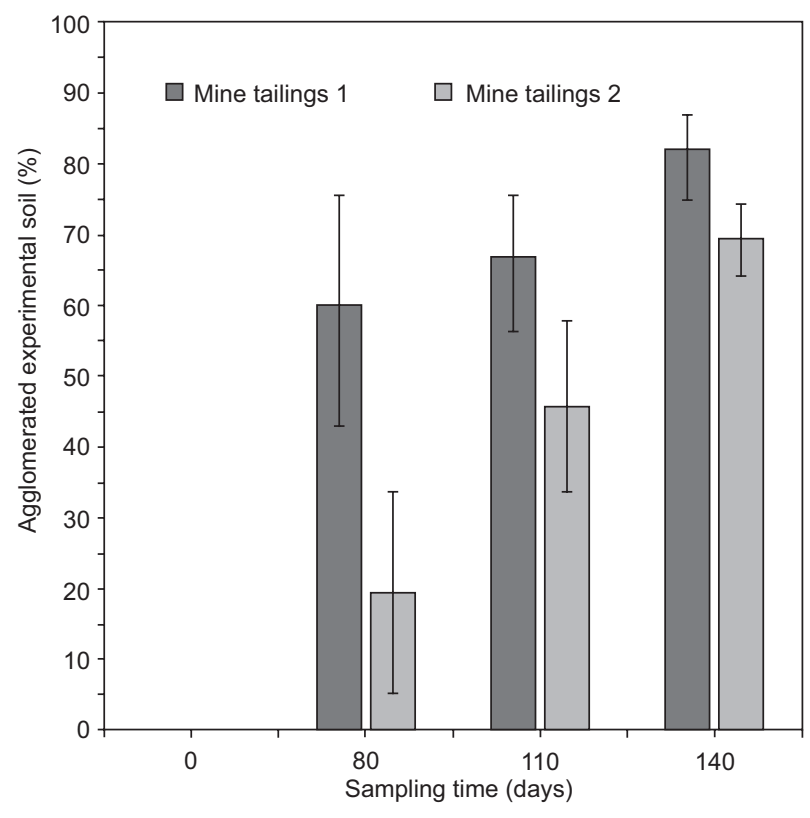

Fig. 3. Agglomerated experimental soil (\%) by plants of Sarcocornia neei

The size particle analysis of the original mine tailings (Fig. 4) showed that the two tailings are equivalent to a sandy soil (particles above $50 \mu \mathrm{m}$ ), and both of them had lower sand content than the beach sand (100\%

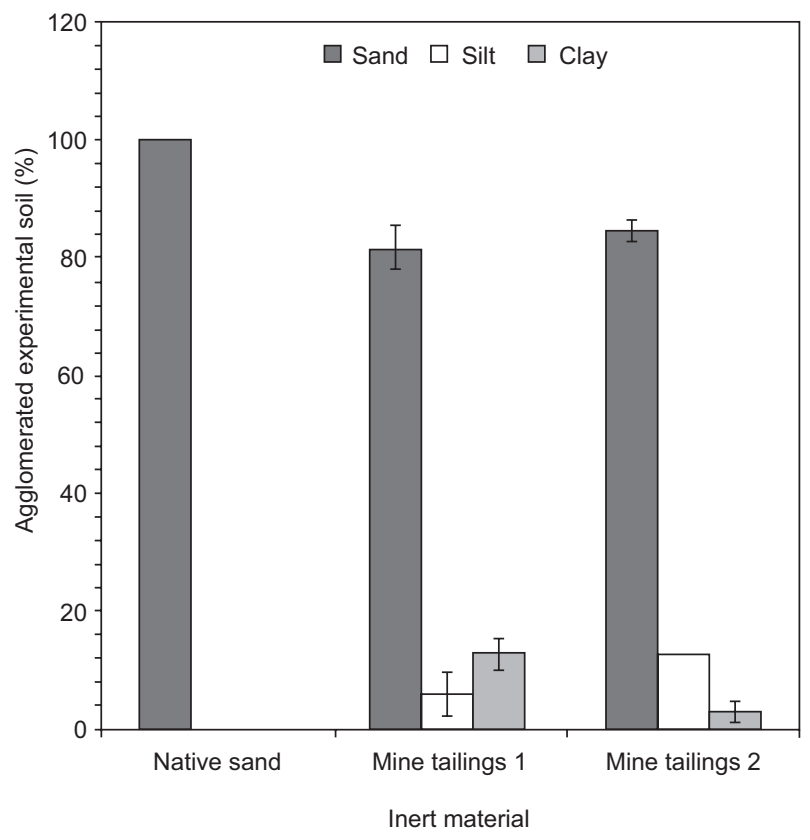

Fig. 4. Size particle fractions (\%) of the inert original materials used in the construction of experimental soils for Sarcocornia neei growing sand) $(\mathrm{p}=0.01$ for mine tailings $1, \mathrm{p}=0.003$ for mine tailings 2). The proportion of sand equivalent in the mine tailings was significantly higher than the proportion of silt and clay $(\mathrm{p}=0.00013)$. The native sand from the beach, did not present particles under $50 \mu \mathrm{m}$; but, the silt content $(50<\mathrm{x}<2 \mu \mathrm{m})$ was significantly higher $(\mathrm{p}=0.00008)$ in mine tailings 2 than 1 , while clay $(\mathrm{x}<2 \mu \mathrm{m})$ was significantly higher in mine tailings $1(12.7 \%, \mathrm{p}=0.01)$ than 2 . The difference in the particle size distribution between mine tailings did not mean a difference in field capacity $(p=0.23)$ between the experimental soils containing different proportion of each mine tailings, then the field capacity of the experimental soils was $20.8+$ $0.8 \%$ of soil weight. According to the soil triangle of Sandoval et al. (2011), the native beach sand was equivalent to sandy soil and the experimental soils containing mine tailings 1 and 2 were equivalent to sandy-loam soil, with different proportions of silt and clay. Then, adding the silt and clay fractions, the mine tailing 1 showed higher fine fraction content than 2 .

\section{DISCUSSION}

The germination rate obtained in this study verifies the ability of S. neei to grow in hostile environments, as is the case of the coastal copper tailings located in the Chañaral province in the Atacama Region. Further, the growth rates verified information obtained from preliminary research, providing evidence of consistent physiological response of this species. Sarcocornia neei is resistant to the chemical elements evaluated in this study, up to the highest concentrations indicated for mine tailings. However, it is possible that the little observed decrease in growth rate may be a symptom of phytotoxicity, due to a partial effect of the elements concentration and/or by other not determined effects by some elements. Mateos-Naranjo et al. (2013) demonstrated high tolerance to stress induced by $\mathrm{Cu}$ in Atriplex halimus (Fam. Chenopodiaceae), then it is important to determine the limit dose of these elements for plant species. Figueroa et al. (1987) demonstrated that Salicornia (Fam. Chenopodiaceae, a species closely related to Sarcocornia), is a metalophyte plant, specifically ferrophilic, storing this element in the canopy at concentrations close to four times (3542.8 ppm) those of the soil (894.7 ppm). In this work, $S$. neei was a ferrophilic plant with high affinity for $\mathrm{Mn}$. The Mn (Figueroa et al. 1987) has high concentration in plants growing in soils with low concentration of $\mathrm{Na}$, and $\mathrm{Fe}$ and the $\mathrm{Mn}$ capture is stimulated in roots from waterlogged conditions. Then, Mn capture from 
the ground by these halophytes plants would appear related to soil and climate conditions. Moreover, Rozema et al. (1985) point out that none of the Salicornia species studied show toxicity by $\mathrm{Mn}$ based on $\mathrm{Mn} / \mathrm{Fe}$ ratios. But, from another perspective, Labronici et al. (2016) analyzed the bioavailable accumulation of $\mathrm{Mg}$ by Sarcocornia ambigua, considering this species as an alternative source of minerals. Then, the presence of Fe and $\mathrm{Mn}$ in $S$. neei, growing in normal environments, could be an alternative source for important mineral nutrition for certain human pathologies.

Several studies have evaluated mixed approaches comprising both liming and vegetation for the management of wetlands contaminated by mine wastes and salts (González-Alcaraz et al. 2011, 2013, Pedro et al. 2015); in these cases the soil was simulated as in the present work. These studies concluded that the components of the soils induced changes in the speciation and potential for mobilization of chemical elements. The variations may be the result of changes in the dynamics of matter transfer in the basin, linked to changes in the water regime of the rivers and streams that make up the Copiapó river basin (Bugueño 2014). The Copiapó River is subjected to strong water stress derived from the exploitation of water by mining and agricultural industries. The effect of the rivers appears only during periods of occasional rains and extraordinary periods of melting in the Cordillera de los Andes.

Calheiros et al. (2012) reported that halophytes offer a promising solution for the treatment of wetland systems contaminated by industrial saline secondary effluent. Idaszkin et al. (2017) indicate that phytoremediation is the most appropriate technique for the restoration of soils contaminated by metals. These authors conclude that Sarcocornia perennis is able to survive in $\mathrm{Pb}$ and $\mathrm{Cu}$ (among others) contaminated soils, and could be a suitable candidate for stabilization of soil by plants.

Andrade et al. (2006) reported that the Bahía Chañaral and Caleta Palito, in Atacama coast, are among the most polluted in the world, due to over 60 years of mine tailings discharge. Wisskirchen and Dold (2006) reported significant concentrations $(\mathrm{mg} / \mathrm{kg})$ of $\mathrm{Cu}$ (1000-24100), Zn (24-223), Ni (5-370), Pb (3- 26), Mo (19-186) and As (30-281) in Bahía Chañaral mine tailings. According to these authors, coastal waters in the area have predominantly been affected by the mentioned elements, while the human population is exposed to pollution by high concentration of $\mathrm{Cu}$ and $\mathrm{Ni}$, as well as relatively lower concentration of Zn (Wisskirchen and Dold 2005). Cáceres (2012) reports the effects of $\mathrm{Cu}$ on the health of children in the Chañaral city (Atacama); which allows to propose that a dense Sarcocornia neei plantation could be a suitable solution to reduce the contamination by the local mine tailings, through the bioabsorption of chemical elements and soil substrate stabilization.

Since these results were obtained from CRIDESAT (University of Atacama), a project with private agents has been actually working (2016-2020) and $S$. neei has been planted in a large area heavily contaminated by active copper mine tailings and watered with the mine process water, which will be reported in the future.

\section{CONCLUSION}

Sarcocornia neei, growing from seedlings, was a plant capable of bioabsorbing elements such as iron, lead, mercury, magnesium and arsenic, from experimentally contaminated soils with mine tailings. On the other hand, the root plant growing allowed a high proportion of agglomeration of the experimental soil. These results were possible because $S$. neei can germinate and grow properly in soil heavily contaminated with mine tailings and in pure tailings, being able to use contaminated water. These abilities of $S$. neei to survive in very inhospitable conditions, and to stabilize the soil, give to this plant species a great regional potential to be used in similar contaminated areas; to create green areas and apply vegetable treatments to these soils.

\section{ACKNOWLEDGMENTS}

Thanks to Mrs. Susana Montecinos, from the Department of Languages of the University of Atacama for her collaboration in the linguistic revision of this work.

\section{REFERENCES}

Alonso M.A., Juan A. and Crespo M.B. (2007). Salicornia-Sarcocornia: ¿una pesadilla o una realidad taxonómica? CIBIO (Instituto de la Biodiversidad), Universidad de Alicante, España, Cuadernos de Biodiversidad 23, 18-20.

Andrade S., Moffett J. and Correa J.A. (2006). Distribution of dissolved species and suspended particulate copper in an intertidal ecosystem affected by copper mine tailings in Northern Chile. Marine Chemistry. https:// doi.org/10.1016/j.marchem.2006.03.002 
Aracena A., Guajardo N., Ibáñez J.P., Jerez O. and Carlesi C. (2015). Uptake of nickel ions from aqueous solutions using protonated dry alginate beads. Can. Metall. Quart. 54 (1), 58-65. https://doi.org/10.1179/1879139 514Y.0000000152

Bugueño M. (2014). Competencia de mecanismos bióticos y abióticos en el transporte de arsénico en el río Loa: Efectos de macrófitas en los flujos y acumulación de arsénico. Tesis de titulación para Doctor en ciencias de la ingeniería. Pontificia Universidad Católica de Chile, Chile, 109 pp.

Cáceres D. (2012). Contaminación por relaves en la zona costera de Chañaral: Efectos en la salud ambiental infantil. Congreso Latinoamericano de Prevención de Riesgos y Medio Ambiente, 7-9 mayo 2012, Santiago de Chile.

Calheiros C.S.C., Quitério P.V.B., Silva G., Crispim L.F.C., Brix H., Moura S.C. and Castro P.M.L. (2012). Use of constructed wetland systems with Arundo and Sarcocornia for polishing high salinity tannery wastewater. J. Environ. Manage. 95, 66-71. https://doi.org/10.1016/j. jenvman.2011.10.003

Cairo P. and Reyes A. (2017). La Fertilidad física del suelo y la agricultura orgánica en el trópico. Editorial Académica Española, Germany, pp. 1-152.

Contreras R., Sepúlveda B., Aguayo F., Porcile V. and Benito C. (2018). Rapid diagnostic PCR method for identification of the genera Sarcocornia and Salicornia. Idesia 36(3): 95-106. https://doi.org/10.4067/S071834292018005001501

Cornejo P., Meier S. and Borie F. (2008). Utilización de hongos micorríticos arbusculares como alternativa para la recuperación de suelos contaminados por actividades mineras. Gestión Ambiental 16, 13-26. https://doi. org/10.1007/s11356-017-8981-x

Costa C. (2011). How do salinity and heavy metal contamination affect Salicornia ramosissima and the cadmium accumulation capacity? Dissertation degree of Master in Biotechnology of Marine Resources, Instituto Politécnico de Leiria, 64 p.

Cunningham S.D. and Ow D.W. (1996). Promises and prospects of phytoremediation. Plant Physiol. 110(3), 715-719. https://doi.org/10.1104/pp.110.3.715

Figueroa E., Jiménez-Nieva J., Carranza J. and González C. (1987). Distribución y nutrición mineral de Salicornia ramosissima J. Woods, Salicornia euopaea L. y Salicornia dolichostachya Moss, en el estuario de los ríos Odiel y Tinto (Huelva, SO España). Limnetica 3(2), 307-310.
Ginocchio R. (1996). Cuantificación de la tolerancia al cobre y al sulfato en dos especies leñosas de Chile central, Rev. Chil. Hist. Nat. 69, 413-424. https://doi. org/10.1016/j.envexpbot.2014.04.004

Ginocchio R. and Baker A. (2004). Metalofitas en América Latina: un recurso biológico y genético único poco conocido y estudiado en la región. Rev. Chil. Hist. Nat. 77, 185-194. https://doi.org/10.4067/S0716078X2004000100014

González-Alcaraz M.N., Conesa H. and Álvarez-Rogel J. (2013). Phytomanagement of strongly acidic, saline eutrophic wetlands polluted by mine wastes: The influence of liming and Sarcocornia fruticosa on metals mobility. Chemosphere 90, 2512-2519. https://doi. org/10.1016/j.chemosphere.2012.10.083.

González-Alcaraza M.N., Conesa H.M., Terceroa M. del C., Schulinb R., Álvarez-Rogela J. and Egea C. (2011). The combined use of liming and Sarcocornia fruticosa development for phytomanagement of salt marsh soils polluted by mine wastes. J. Hazard. Mater. 186, 805813 https://doi.org/10.1016/j.jhazmat.2010.11.071.

Iannacone J. and Alvariño L. (2005). Efecto ecotoxicológico de tres metales pesados sobre el crecimiento radicular de cuatro plantas vasculares. Agricultura Técnica 65(2), 198-203. https://doi.org/10.4067/ S0365-28072005000200009.

Idaszkin Y.L., Lancelotti J.L., Pollicelli M.P., Marcovecchio J.E. and Bouza P.J. (2017). Comparison of phytoremediation potential capacity of Spartina densiflora and Sarcocornia perennis for metal polluted soils. Mar. Pollut. Bull. 118, 297-306. https://doi.org/10.1016/j. marpolbul.2017.03.007.

Labronici R., Maltez H.F., de Gois J.S., Borges D.L.G., Campelo G. da S., Gonzaga L.V., Fetta R. (2016). Mineral composition and bioaccessibility in Sarcocornia ambigua using ICP-MS. J. Food Comp. Anal. 47, 45-51. https://doi.org/10.1016/j. jfca.2015.12.009.

Lambert H., Chapin III F.S. and Pons T.L. (1998). Plant physiological ecology. Springer-Verlag, New York, USA. pp. 1-540.

Lasat M.M.J. (2002). Phitoextraction of toxic metals: a review of biological mechanisms. J. Environ. Qual. 31, 109-120. https://doi.org/10.2134/jeq2002.0109

Mateos-Naranjo E., Andrades-Moreno L., Cambrolle J. and Pérez-Martin A. (2013). Assessing the effect of copper on growth, copper accumulation and physiological responses of grazing species Atriplex halimus: Ecotoxicological implications. Ecotoxicol. 
Environ. Safe. 90, 136-142. https://doi.org/10.1016/j. ecoenv.2012.12.020

Montenegro G., Fredes C., Mejías E., Bonomelli C. and Olivares L. (2009). Contenido de metales pesados en suelos cercanos a un relave cuprífero. Agrociencia 43, 427-435.

Pedro S., Duarte B., Raposo de Almeida P. and Caçador I. (2015). Metal speciation in salt marsh sediments: Influence of halophyte vegetation in salt marshes with different morphology. Estuar. Coast. Shelf Sc. 167, 248-255. https://doi.org/10.1016/j.ecss.2015.05.034

Reeves R.D. and Baker A. (2000). Metal accumulating plants. In: Phytoremediation of toxic metals: using plants to clean up the environment (I. Raskin and B. Ensley, Eds.). Wiley and Sons, New York, pp. 193-229.

Reeves R.D. (2003). Tropical hyperaccumulators of metals and their potential for phytoextraction. Plant Soil 249, 57-65. 2003. https://doi. org/10.1023/A:1022572517197.

Rozema J., Luppes E. and Broekmann R. (1985). Differential response of salt-marsh species to variation of iron and manganese. Vegetatio, 62: 293-301. https:// doi.org/10.1007/BF00044756

Sadzawka A., Carrasco M.A., Demanet R., Flores H., Grez R., Mora M., Neaman A. and Romeny G. (2007). Guía para la validación de los métodos de análisis de lodos y de suelos. Comisión de Normalización y Acreditación (CNA) de la Sociedad Chilena de la Ciencia del Suelo, pp. 1-115.

Sandoval M., Dörner J., Seguel O., Cuevas J. and Rivera D. (2011). Métodos de análisis físico de suelos. Comisión de Física de Suelos de la Sociedad Chilena de la Ciencia del Suelo, 75 pp.

Sepúlveda B., Pavez O. and Tapia M. (2012). Fitoextracción de metales pesados desde relaves utilizando plantas de Salicornia sp. Revista Facultad de Ingeniería, Universidad de Atacama, 28, 20-26.

Sepúlveda B., Tapia P. and Pavez O. (2017). Capacidad metalófila de Sarcocornia y estabilización de relaves mineros, III Región, Chile. $17^{\circ}$ Congreso Internacional de Metalurgia y Materiales CONAMET-SAM, 18-20 de Octubre de 2017. Copiapó-Chile.

Wisskirchen C. and Dold B. (2005). Hydrogeochemistry of the marine shore porphyry copper tailings deposit at Chañaral, Atacama desert, Northern Chile. $3^{\text {rd }}$. Swiss Geoscience Meeting, Zurich, pp.18-19.

Wisskirchen C. and Dold B. (2006). The marine shore porphyry copper mine tailings deposit at Chañaral, Northern Chile. $7^{\text {th }}$ Conference on Acid Rock Drainage (ICARD), march 26-30, St. Louis MO, pp. 2480-2489. 